\title{
Red Globe Üzüm Çeşidinde Farklı Anaç Kombinasyonlarının Açık Köklü Aşılı Fidan Randımanları Üzerine Etkileri
}

\author{
Sümeyya Akçaman iD Alper Dardeniz ${ }^{*}$ iD \\ ${ }^{1}$ ÇOMÜ Ziraat Fakültesi, Bahçe Bitkileri Bölümü. 17100, Çanakkale. \\ *Sorumlu yazar: adardeniz@comu.edu.tr \\ Geliş Tarihi: 06.09.2021 \\ Kabul Tarihi: 03.11.2021 \\ $\ddot{\mathbf{O z}}$ \\ $\mathrm{Bu}$ araştırma, 'Red Globe' üzüm çeşidinde farklı anaç kombinasyonlarının açık köklü aşılı fidan \\ randımanları üzerine etkilerinin belirlenmesi amacıyla 2016 yılında, Manisa ilindeki 'Çalışkan Asma Fidancılığı' \\ işletmesinde yürütülmüştür. Araştırmada 'Red Globe' üzüm çeşidinin kalemleri, '5BB', '41B', '110R', '1103P' \\ ve '1613C' anaçlarının aşılanabilir çelikleri üzerine masa başı omega aşı yöntemiyle aşılanmıştır. Araştırma 3 \\ tekerrürlü ve her bir tekerrürde 50'şer adet aşılı çelik yer alacak şekilde planlanmıştır. En yüksek fidanlık \\ randımanı Red Globe/110R (\%76,00), en düşük fidanlık randımanı Red Globe/41B (\%44,67) çeşit/anaç \\ kombinasyonunda, en yüksek 1. boy aşılı asma fidanı randımanı Red Globe/110R $(\% 53,33)$, en düşük 1 . boy \\ aşılı asma fidanı randımanları ise sırasıyla Red Globe/41B (\%30,00), Red Globe/5BB (\%30,00) ve Red \\ Globe/1103P $(\% 36,00)$ çeşit/anaç kombinasyonlarında tespit edilmiştir.
}

Anahtar Kelimeler: Red Globe üzüm çeşidi, Açık köklü aşılı fidan, Fidan randımanı, 1. boy fidan randımanı.

\section{The Effects of Different Rootstock Combinations on Bare Root Grafted Sapling Yields of Red Globe Grape Variety Abstract}

This research was carried out in the 'Caliskan Vine Arboriculture' management in Manisa province in 2016 in order to determine the effects of different rootstock combinations on bare root grafted sapling yields in the 'Red Globe' grape variety. In the research, the scions of the 'Red Globe' grape variety were grafted onto the graftable cuttings of the '5BB', '41B', '110R', '1103P' and '1613C' rootstocks using the omega grafting method. The study was planned with 3 replications and 50 grafted cuttings in each replication. The highest sapling yield was determined in Red Globe/110R (76.00\%), and the lowest sapling yield was obtained from Red Globe/41B variety/rootstock combination. The highest $1^{\text {st }}$ length grafted grapevine yield was determined in Royal Globe/110R (53.33\%), the lowest $1^{\text {st }}$ length grafted grapevine yield was established Red Globe/41B (30.00\%), Red Globe/5BB (30.00\%) and Red Globe/1103P (36.00\%) variety/rootstock combinations, respectively.

Keywords: Red Globe grape cultivar, Bare root grafted sapling, Sapling yield, $1^{\text {st }}$ length grafted grapevine yield.

\section{Giriş}

Ülkemizde 2017 yılında 3826412 adet, 2018 yllında 2276000 adet ve 2019 yllında ise 3054 188 adet sertifikalı asma fidanı üretilmiştir (Anonim, 2020).

Ülkemizin bağ alanlarının birçoğu filoksera (Viteus vitifolii Fitch.) zararlısı ile bulaşık durumdadır (İlter ve ark., 1984). Ülkemizde filoksera zararlısının bulaşık olduğu bölgelerde, direkt olarak Vitis vinifera çeşitlerinden alınan kalemlerin köklendirilmesi ile bağ kurulması mümkün değildir. Ancak bu zararlıya dayanıklı olan Amerikan asma anaçlarının kullanılması ile sağlıklı ve kârlı bir üzüm yetiştiriciliği yapılabilmektedir (Çelik ve ark., 1998; Dardeniz ve ark., 2005).

Fidanlık koşullarında yapılan üretimde en az kayıp ile üstün özellikli fidanların elde edilebilmesi için, uygun anaç ve çeşit/anaç kombinasyonlarının seçilerek üretim yapılması önem taşımaktadır (Cangi, 1998). Anaçların, üzerine aşılandıkları çeşit ile olan uyumları yalnızca kaynaştırma odası ile fidan kalite ve randımanına değil, bağdaki çeşidin verim ve kalite oranına da önemli düzeyde etki göstermektedir (Kısmal1, 1978).

Fidan üretiminde Vinifera çeşitlerine ait olan tek gözlü kalemler, Amerikan asma anaçlarına ait çelikler üzerine masa başında aşılanmaktadır. Aşı yerinde kontrollü şartlarda gerçekleşen 
kaynaşmadan sonra aşılı çeliklerin fidanlık ya da sera şartlarında köklendirilmesinin ardından elde edilmiş olan asma fidanlarına açık köklü aşılı fidan ismi verilmektedir. Son zamanlarda omega aşı makineleriyle yapılan masabaşı aşılama yöntemi kısa zamanda çok fazla oranda fidan elde etmek amacıyla yaygın bir şekilde kullanılarak tercih edilmektedir.

Çeşit/anaç kombinasyonlarında iyi ve kaliteli şekilde kallus ve kök oluşumu çelik kalınlığına (Dardeniz ve ark., 2008), odunlaşma seviyesine (Dardeniz, 2001; Dardeniz ve ark., 2007; Dardeniz ve ark., 2008), çeşit ve anaç özelliğine (Dardeniz, 2001), muhafaza koşullarına (Balo ve Balo 1969; Kısmal1, 1981; Tırpancı ve Dardeniz 2014), çimlendirme sırasındaki ortam şartlarına (Alço ve ark., 2015), sürgün ve çeliklerin hazırlanma tarihlerine (Kısmal1, 1978; Dardeniz ve ark., 2007), farkl1 çeşit/anaç kombinasyonlarına (Tuncel ve Dardeniz, 2013; Alço ve ark., 2015) ve fidanlık parselindeki dikim seviyesi yüksekliğine (Dardeniz ve ark., 2013) göre değişiklikler gösterebilmektedir.

Serada tüplü (kaplı) aşılı fidan randımanlarımız \%60-75 düzeylerinde değişmektedir. Ancak, açık köklü aşılı fidan randımanlarımız daha düşük olup, bu değer klasik eski sistem tek sıra çiziye dikim yönteminde \%33-34 iken, malç-damla sulama kombinasyonlu çift sıra tepe (yüzlek) dikim yönteminde \%46-47 seviyelerine ancak yükseltilebilmiştir (Dardeniz ve ark., 2015). Açık köklü aşılı fidan randımanlarımızın yeni teknik ve yöntemlerin takibiyle arttırılmasına çalışılmalıdır.

$\mathrm{Bu}$ gün bile anaç ile kalem arasında ortak yaşamı sağlayan veya engelleyen faktörler tamamen açıklığa kavuşturulamamış olup bu durum ancak yoğun araştırmalarla ortaya konulabilir. Örneğin; günümüzde aşıda sorun yaşanan bazı aşı kombinasyonlarına; Red Globe/5BB, Red Globe/1103P, Yuvarlak Çekirdeksiz/41B, Superior Seedless/41B, Alphonse Lavallée/41B, Trakya İlkeren/41B, Syrah/41B, Razak1/41B Superior Seedless/5BB, Atasarısi/99R ve Atasarı1/420A örnek olarak verilebilir. Aşı tutma oranının düşük olması veya aşıların tutmaması bir uyuşmazlık belirtisi olarak görülse de, randıman düşüklüğü gözlenen her kombinasyonun uyuşmaz olduğunu belirtmek de doğru değildir. Nitekim 41B anacının köklü çeliklerini kullanan Kısmalı (1979), bu durumda randımanın 3 kattan fazla yükseldiğini ve esas sorunun bazı anaçlardaki güç köklenmeden ileri geldiğini ifade etmektedir. Günümüzde henüz, bütün mevcut üzüm çeşitleriyle iyi uyuşan ve her türlü iklim ve toprak koşullarında yetişen ideal bir anaç mevcut bulunmamaktadır.

Bazı virüs hastalıklarından dolayı anaç ile kalemin kaynaşamaması, birçok araştırıcı tarafından uyuşmazlık olarak kabul edilmektedir. Bazı kombinasyonlarda toksik etkiyi yapan madde virüs kaynaklı olabilir. Örneğin Çanakkale ili şartlarında; Red Globe üzüm çeşidi özellikle 1103P ve 5BB anaçları üzerine aşılandığında, fidanlık şartlarında ileriki dönemlerde çökme yaparak randıman düşüklüğü meydana gelebilmektedir. Red Globe/41B ve Red Globe/140Ru aşı kombinasyonlarında ise bir sorun yaşanmamaktadır. Red Globe üzüm çeşidinin kendine has bu virüs hastalığı haziran ayı başından itibaren ortaya çıkmaktadır. Genel olarak, fidan gelişimi yavaşlayarak yapraklarda giderek artan bir solgunluk ve sararma görülmekte, aşılı çeliğin kök bölgesinde çürümeler olmakta ve belirli bir boya ulaşamayan fidanlarda çökme ve kuruma meydana gelmektedir. Belirli bir boya ulaşan fidanlarda ise zarar görülmemektedir. Böylece, bazı anaçlar üzerinde \%20-30'a varan oranda kayıplar meydana gelmekte, böyle fidanlar parselden uzaklaştırmak mecburiyetinde kalınmaktadır (Dardeniz, 2011).

Asmalarda yaprak kıvırcıklığı hastalığına neden olan 'Grapevine Red Globe Virus' (GRGV) 'Grapevine Fleck Virus' benzeri virüslerden olup, Vitis türlerinde bulunmuş olan 47. virüstür (Walter ve Martelli,1997; Sabanadzovic ve ark., 2000).

İlk olarak 2000'de güney İtalya'da ve daha sonra Yunanistan ve Kaliforniya'da tanımlanmış olan ve çoğaltım ve aşılama yoluyla yayıldığı düşünülen GRGV, daha sonra Fransa'da da bulunmuştur. Yakın akrabası olan 'Grapevine Fleck Virus'e benzer şekilde, Vitis vinifera ve anaçlarda canlılık, köklenme yeteneği ve aşı uyuşmasını etkileyen gizli veya yarı gizli enfeksiyonlara neden olabileceği belirtilmektedir (Beuve ve ark., 2015).

Bariz semptomlara neden olmayan ve varsa asmalar üzerindeki potansiyel etkisi çok fazla bilinmeyen GRGV virüsünün, Çin'in Liaoning Eyaleti'nde klorotik beneklenme sergileyen ve Vitis vinifera'nın aşılanması için anaç olarak kullanılan 'Beta' asmalarındaki varlığı yakın zamanda doğrulanmıştır. GRGV, şaraplık üzüm çeşitlerinden Cabernet Franc, Cabernet Sauvignon ve Chardonnay üzüm çeşitlerinde de bulunmuş, konunun aydınlatılması üzerine daha fazla çalışmaya ihtiyaç olduğu belirtilmiştir (Fan ve ark., 2016).

Farklı anaçlar (1103P ve 110R) üzerine aş1lı Red Globe üzüm çeşidinin açık köklü aşılı 
fidanlarının incelemeye alındığı bir araştırmada; Red Globe/1103P $(87,90 \mathrm{~cm})$ ve Red Globe/110R $(91,38 \mathrm{~cm})$ çeşit/anaç kombinasyonları arasında ana sürgün uzunluğu parametresinde önemli bir farklılık oluşmamıştır. Red Globe/1103P (4,69 adet) ve Red Globe/110R (5,05 adet) çeşit/anaç kombinasyonlarının koltuk sürgünü sayısı parametresinde yine önemli bir farklılık belirlenememiştir. Red Globe/1103P (5,15 mm) ve Red Globe/110R (5,87 mm) çeşit/anaç kombinasyonlarının sürgün çapı parametresi arasında önemli farklılık tespit edilmiştir. Benzer şekilde, Red Globe/1103P (10,39 adet) ve Red Globe/110R (8,05 adet) çeşit/anaç kombinasyonlarının ana kök sayısı parametrelerinde önemli farkl11ıklar belirlenmiş̧ir (Eroğlu, 2014).

Gaziantep ilinde yürütülen bir araştırmada Red Globe/110R çeşit/anaç kombinasyonunda; kök sayısı: 9,0 adet, kök gelişim düzeyi: 3,0, sürgün gelişim düzeyi: 3,0, I. boy fidan randımanı: $\% 44,0$, II. boy fidan randımanı: \%16,0 ve toplam fidan randımanı: \%60,0, Red Globe/99R çeşit/anaç kombinasyonunda; kök sayısı: 7,0 adet, kök gelişim düzeyi: 2,0, sürgün gelişim düzeyi: 2,0, I. boy fidan randımanı: 41,8, II. boy fidan randımanı: 33,5 ve toplam fidan randımanı: 75,3 olarak belirlenmiştir (Aslan ve ark., 2015).

Red Globe UC patentli dünya çapında bir sofralık üzüm çeşidi olup, Kaliforniya da ilk nesil sofralık üzüm bağlarının başlangıcı kendi kökleri üzerine dikilmeleri şeklinde gerçekleşmiştir. İlerleyen yıllarda, nematod ve diğer problemler sebebiyle plantasyonların yenilenmesi gerekmiştir. Luvisi D. isimli araştırmacı, Kern County bağlarında bu üzüm ile ilgili bir takım problemleri tespit etmiş̧ir. Luvisi D., 1996 yılında deneme bağında Red Globe üzüm çeşidinin 5BB, 3309C ve 1103P üzerine aşılanmış olan asmalarının 2. yıllarında öldüklerini, kendi kökü üzerine yetiştirilen Red Globe üzüm çeşidine ait omcaların ise yaşamlarını devam ettirdiğini tespit etmiştir. Red Globe üzüm çeşidi ile daha fazla anaç üzerinde yeni çalışmaların yapılmasının gerekliliğini belirtmiştir (Uyemoto ve ark., 2000).

Bu araştırma, Red Globe üzüm çeşidinde farklı anaç kombinasyonlarının açık köklü aş11ı fidan randımanları üzerine etkilerinin belirlenmesi amacıyla yürütülmüştür.

\section{Materyal veYöntem}

$\mathrm{Bu}$ araştırma, Manisa ilinde bulunan 'Çalışkan Asma Fidancılı̆̆ içerisinde yürütülmüştür. Araştırmada Red Globe üzüm çeşidinin kalemleri 5BB, 41B, 110R, 1103P ve 1613C anaçlarının aşılanabilir çeliklerinin üzerine aşılanmıştır.

Çeşit damızlığı parselinden kış budaması sırasında (Ocak-Şubat) alınan kalemler demetler halinde polietilen torbalar içinde, soğuk depoda kontrollü koşullarda $\left(1-4^{\circ} \mathrm{C}\right.$ ve $\% 80-85$ nem) muhafaza edilmiştir. Aralık-Ocak ayları içerisinde ise anaç damızlığı parsellerinden yaklaşık $40 \mathrm{~cm}$ uzunluğundaki aşılanabilir çelikler hazırlanmıştır.

Tek gözlü olarak hazırlanmış Red Globe üzüm çeşidine ait kalemler ile gözleri köreltilmiş aşılanabilir (aşılık) çelikler, 2016 yılı üretimi sezonunda 'Çalışkan Asma Fidancılığı'na ait aşı üretim tesisinde pedallı tip omega aşı makinalarında aşılanmıştır.

Her bir çeşit/anaç kombinasyonuna ait aşılı çelikler, Richter sandıkları içerisine çimlendirme ortamı olarak ince çam talaşı konularak, tesadüf parselleri deneme desenine göre 3 tekerrür ve her tekerrürde 50'şer adet aş11 çelik olacak şekilde sandıklara yerleştirilmiş ve çimlendirme odasına alınmıştır. Aşılı çeliklerin bulunduğu çimlendirme odası ortamı 3 hafta süreyle $22^{\circ} \mathrm{C}$ 'den $27^{\circ} \mathrm{C}$ 'ye kadar kademeli olarak arttırılmış ve bağıl nem oranı ise \%80-85 düzeyinde tutulmuştur. Aşılı çelikler 3 haftanın sonunda 3-4 gün süren bir alıştırma dönemine alınmıştır.

Araştırmada fidanlık randımanı (\%), 1. boy aşılı asma fidanı randımanı (\%), anaç kalınlı̆̆ $(\mathrm{mm})$, 1.-2. boğum arası kalınlığı $(\mathrm{mm})$, 5.-6. boğum arası kalınlığı $(\mathrm{mm})$, 9.-10. boğum arası kalınlığı $(\mathrm{mm}), 13 .-14$. boğum arası kalınlığ $(\mathrm{mm})$, aşı noktası kalınlığı $(\mathrm{mm})$, ana sürgün uzunluğu $(\mathrm{cm})$, ana sürgündeki boğum sayıs1 (adet), ana sürgün boğum uzunluğu ortalamas1 $(\mathrm{cm})$, ana sürgün üzerindeki koltuk sürgünü sayısı (adet), koltuklar üzerindeki boğum sayısı (adet), toplam boğum sayısı (adet), yan kök sayısı (adet), dip kök sayısı (adet), toplam kök sayısı (adet), dip kök uzunluğu ortalaması $(\mathrm{cm})$ ve dip kök skalası (0-4) parametreleri incelenmiştir.

Tesadüf parselleri deneme desenine göre kurulan araştırmadan elde edilmiş olan bulgular; 'SAS 9.1.3 portable' istatistik paket programı kapsamında varyans analizine tabi tutulmuş olup, uygulamalara ait ortalama değerler ise LSD çoklu karşılaştırma testine göre değerlendirilmiştir. 


\section{Bulgular ve Tartışma}

Red Globe üzüm çeşidinde farklı anaç kombinasyonlarının açık köklü aşılı fidan randımanları üzerine etkilerinin belirlenmesi amacıyla yürütülmüş olan bu araştırmadan elde edilen bulgular Çizelge 1., Çizelge 2., Çizelge 3., Çizelge 4. ve Çizelge 5.’te sunulmuştur.

Açık köklü aşılı fidanlardaki en yüksek fidanlık randımanı Red Globe/110R $(\% 76,00)$ çeşit/anaç kombinasyonunda, en düşük fidanlık randımanı Red Globe/41B $(\% 44,67)$ kombinasyonunda bulunmuş, diğer çeşit/anaç kombinasyonları ise ara grubu oluşturmuştur. En yüksek 1. boy aşılı asma fidanı randımanı Red Globe/110R $(\% 53,33)$ çeşit/anaç kombinasyonunda, en düşük 1. boy aşı1ı asma fidanı randımanı değeri Red Globe/41B (\%30,00) ile Red Globe/5BB $(\% 30,00)$ çeşit/anaç kombinasyonlarında tespit edilmiştir. Anaç kalınlığ 1 parametresinde farklı çeşit/anaç kombinasyonları bazında önemli bir farklılık meydana gelmediği görülmektedir (Çizelge 1.).

Çizelge 1. Açık köklü aşılı fidanlarda randımanlar ile vejetatif gelişime ait bazı özellikler

\begin{tabular}{llll}
\hline $\begin{array}{l}\text { Çeşit/anaç } \\
\text { kombinasyonu }\end{array}$ & $\begin{array}{l}\text { Fidanlık } \\
\text { randımanı }(\%)\end{array}$ & $\begin{array}{l}\text { 1. boy aşılı asma } \\
\text { fidanı randımanı }(\%)\end{array}$ & $\begin{array}{c}\text { Anaç } \\
\text { kalınlı̆̆ }(\mathrm{mm})\end{array}$ \\
\hline Red Globe/41B & $44,67 \mathrm{c}$ & $30,00 \mathrm{~b}$ & 12,25 \\
Red Globe/1103P & $62,00 \mathrm{~b}$ & $36,00 \mathrm{~b}$ & 11,21 \\
Red Globe/1613C & $65,33 \mathrm{~b}$ & $48,00 \mathrm{a}$ & 11,75 \\
Red Globe/110R & $76,00 \mathrm{a}$ & $53,33 \mathrm{a}$ & 12,16 \\
Red Globe/5BB & $63,33 \mathrm{~b}$ & $30,00 \mathrm{~b}$ & 11,44 \\
\hline \multicolumn{1}{c}{ LSD* } & 9,2048 & 7,1548 & OD \\
\hline
\end{tabular}

$* \mathrm{P}<0,05$ düzeyinde önemli. ÖD: Önemli değil ( $\mathrm{P}>0,05)$.

Açık köklü aşılı fidanlardaki en yüksek 1.-2. boğum arası kalınlığı değerleri sırasıyla Red Globe/110R (5,94 mm) ve Red Globe/41B (5,79 mm), en düşük 1.-2. boğum arası kalınlığı değeri Red Globe/1103P $(4,42 \mathrm{~mm})$ çeşit/anaç kombinasyonlarından alınmış, diğer kombinasyonlar ise ara grubu oluşturmuştur. En yüksek 5.-6. boğum arası kalınlığı Red Globe/41B $(5,38 \mathrm{~mm})$ çeşit/anaç kombinasyonlarından, en düşük 5.-6. boğum arası kalınlı̆̆ sırasıyla Red Globe/1103P (3,24 mm) ve Red Globe/5BB $(3,70 \mathrm{~mm})$ çeşit/anaç kombinasyonlarından elde edilmiş, diğer kombinasyonlar ara grubu teşkil etmiştir. En yüksek 9.-10. boğum arası kalınlığı Red Globe/110R (3,45 mm) çeşit/anaç kombinasyonundan elde edilmiş, sirasiyla Red Globe/1103P (2,03 mm), Red Globe/5BB (2,26 mm) ve Red Globe/1613C (2,67 mm) çeşit/anaç kombinasyonlarından en düşük kalınlık değerleri alınmış, Red Globe/41B çeşit/anaç kombinasyonu ara grubu meydana getirmiştir. En yüksek 13.-14. boğum aras1 kalınlığı değerlerini Red Globe/110R (2,83 mm) çeşit/anaç kombinasyonu oluştururken, sırasıyla Red Globe 5BB (1,32 mm) ve Red Globe/1103P $(1,56 \mathrm{~mm})$ çeşit/anaç kombinasyonları en düşük değerleri vermiş, diğer çeşit/anaç kombinasyonları ara gurubu oluşturmuştur (Çizelge 2.).

Çizelge 2. Açık köklü aşılı fidanlarda aşı sürgünlerinin boğum arası kalınlıklarına ait veriler

\begin{tabular}{|c|c|c|c|c|c|}
\hline $\begin{array}{l}\text { Çeşit/anaç } \\
\text { kombinasyonu }\end{array}$ & $\begin{array}{l}\text { 1.-2. boğum arası } \\
\text { kalınlığ } 1 \\
(\mathrm{~mm})\end{array}$ & $\begin{array}{l}\text { 5.-6. boğum aras1 } \\
\text { kalınlığ } 1 \\
(\mathrm{~mm})\end{array}$ & $\begin{array}{l}9 .-10 . \\
\text { aras1 } \\
(\mathrm{mm})\end{array}$ & $\begin{array}{c}\text { boğum } \\
\text { kalınlığg }\end{array}$ & $\begin{array}{l}\begin{array}{l}\text { 13.-14. } \\
\text { aras1 } \\
(\mathrm{mm})\end{array} \\
\text { kalığulığ } \\
\end{array}$ \\
\hline Red Globe/41B & $5,79 \mathrm{a}$ & $5,38 \mathrm{a}$ & $2,77 \mathrm{ab}$ & & $2,15 \mathrm{ab}$ \\
\hline Red Globe/1103P & $4,42 \mathrm{~b}$ & $3,24 \mathrm{~b}$ & $2,03 \mathrm{~b}$ & & $1,56 \mathrm{~b}$ \\
\hline Red Globe/1613C & $4,92 \mathrm{ab}$ & $4,02 \mathrm{ab}$ & $2,67 \mathrm{~b}$ & & $1,82 a b$ \\
\hline Red Globe/110R & $5,94 \mathrm{a}$ & $4,49 a b$ & $3,45 \mathrm{a}$ & & $2,83 \mathrm{a}$ \\
\hline Red Globe/5BB & $4,98 \mathrm{ab}$ & $3,70 \mathrm{~b}$ & $2,26 \mathrm{~b}$ & & $1,32 \mathrm{~b}$ \\
\hline LSD* & 1,0392 & 1,4048 & 0,7392 & & 1,1232 \\
\hline
\end{tabular}

$* \mathrm{P}<0,05$ düzeyinde önemli.

Açık köklü aşı1ı fidanlardaki en yüksek aşı noktası kalınlığ sırasıyla Red Globe/5BB (23,31 $\mathrm{mm})$, Red Globe/41B (22,85 mm), Red Globe/1103P (22,71 mm) ve Red Globe/110R (22,02 mm) çeşit/anaç kombinasyonlarında, en düşük aşı noktası kalınlığı Red Globe/1613C (19,15 mm) çeşit/anaç kombinasyonunda saptanmıştır. En yüksek ana sürgün uzunluğu Red Globe/110R $(36,00 \mathrm{~cm})$ çeşit/anaç kombinasyonunda, en düşük ana sürgün uzunluğu Red Globe/1103P $(20,40 \mathrm{~cm})$ çeşit/anaç kombinasyonunda belirlenmiş, diğer çeşit/anaç kombinasyonları ara grupları oluşturmuştur. En yüksek ana sürgündeki boğum sayısı sırasıyla Red Globe/110R (12,86 adet), Red Globe/41B (12,56 adet) ve 
Red Globe/1613C ((11,93 adet) çeşit/anaç kombinasyonlarında, en düşük ana sürgündeki boğum sayıs1 Red Globe/1103P (9,37 adet) çeşit/anaç kombinasyonunda elde edilirken, Red Globe/5BB çeşit/anaç kombinasyonu ara grubu teşkil etmiştir. En yüksek ana sürgün boğum uzunluğu ortalaması Red Globe/110R $(2,63 \mathrm{~cm})$ çeşit/anaç kombinasyonunda, en düşük ana sürgün boğum uzunluğu ortalaması Red Globe/1103P (2,15 cm) çeşit/anaç kombinasyonunda elde edilmiş, diğer çeşit/anaç kombinasyonları ara grupları meydana getirmiştir (Çizelge 3.).

Çizelge 3. Açık köklü aşılı fidanlarda vejetatif gelişime ait bazı özellikler

\begin{tabular}{|c|c|c|c|c|}
\hline \multirow[b]{2}{*}{ Çeşit/anaç kombinasyonu } & \multirow[b]{2}{*}{$\begin{array}{l}\text { Aşı noktası } \\
\text { kalınlığı }(\mathrm{mm})\end{array}$} & \multirow[b]{2}{*}{$\begin{array}{l}\text { Ana sürgün } \\
\text { uzunluğu }(\mathrm{cm})\end{array}$} & Ana sürgündeki & \multirow{2}{*}{$\begin{array}{l}\text { Ana sürgün } \\
\text { boğum uzunluğu } \\
\text { ortalamasi }(\mathrm{cm})\end{array}$} \\
\hline & & & $\begin{array}{l}\text { boğum } \\
\text { (adet) }\end{array}$ & \\
\hline Red Globe/41B & $22,85 \mathrm{a}$ & $31,67 \mathrm{ab}$ & $12,56 \mathrm{a}$ & $2,56 \mathrm{ab}$ \\
\hline Red Globe/1103P & $22,71 \mathrm{a}$ & $20,40 \mathrm{c}$ & $9,37 \mathrm{~b}$ & $2,15 \mathrm{c}$ \\
\hline Red Globe/1613C & $19,15 \mathrm{~b}$ & $27,81 \mathrm{~b}$ & $11,93 \mathrm{a}$ & $2,23 \mathrm{bc}$ \\
\hline Red Globe/110R & $22,02 \mathrm{a}$ & $36,00 \mathrm{a}$ & $12,86 \mathrm{a}$ & $2,63 \mathrm{a}$ \\
\hline Red Globe/5BB & $23,31 \mathrm{a}$ & $25,85 \mathrm{bc}$ & $11,54 \mathrm{ab}$ & $2,21 \mathrm{bc}$ \\
\hline LSD* & 2,3778 & 6,2909 & 2,4061 & 0,3845 \\
\hline
\end{tabular}

*P<0,05 düzeyinde önemli.

Açık köklü aşılı fidanlardaki en yüksek ana sürgün üzerindeki koltuk sürgünü sayısı Red Globe/110R (2,35 adet) çeşit/anaç kombinasyonunda, en düşük ana sürgün üzerindeki koltuk sürgünü sayıs1 sirasiyla Red Globe/5BB (1,48 adet), Red Globe/1103P (1,57 adet) ve Red Globe/41B (1,66 adet) çeşit/anaç kombinasyonlarından elde edilmiş, Red Globe/1613C çeşit/anaç kombinasyonu ise ara grubu oluşturmuştur. En yüksek koltuklar üzerindeki boğum sayısı Red Globe/110R (11,48 adet) çeşit/anaç kombinasyonu, en düşük koltuklar üzerindeki boğum sayısı sırasıyla Red Globe/5BB (4,34 adet), Red Globe/1103P (5,98 adet) ve Red Globe/41B (6,33 adet) çeşit/anaç kombinasyonlarından alınmış, Red Globe/1613C çeşit/anaç kombinasyonu ise ara grubu meydana getirmiştir. En yüksek toplam boğum sayıs1 Red Globe/110R (24,34 adet), en düşük toplam boğum sayıs1 sirasiyla Red Globe/1103P (15,34 adet) ve Red Globe/5BB (15,88 adet) çeşit/anaç kombinasyonlarında belirlenmiş, diğer çeşit/anaç kombinasyonları ara grubu teşkil etmiştir (Çizelge 4.).

Çizelge 4. Açık köklü aşı1ı fidanlarda vejetatif gelişime ait bazı özellikler

\begin{tabular}{|c|c|c|c|}
\hline $\begin{array}{l}\text { Çeşit/anaç } \\
\text { kombinasyonu }\end{array}$ & $\begin{array}{l}\text { Ana sürgün üzerindeki } \\
\text { koltuk sürgünü sayıs } \\
\text { (adet) }\end{array}$ & $\begin{array}{l}\text { Koltuklar üzerindeki } \\
\text { boğum sayısı } \\
\text { (adet) }\end{array}$ & $\begin{array}{l}\text { Toplam boğum } \\
\text { Sayis1 } \\
\text { (adet) }\end{array}$ \\
\hline Red Globe/41B & $1,66 \mathrm{~b}$ & $6,33 \mathrm{~b}$ & $18,87 \mathrm{ab}$ \\
\hline Red Globe/1103P & $1,57 \mathrm{~b}$ & $5,98 \mathrm{~b}$ & $15,34 \mathrm{~b}$ \\
\hline Red Globe/1613C & $2,00 \mathrm{ab}$ & $7,26 \mathrm{ab}$ & $19,20 \mathrm{ab}$ \\
\hline Red Globe/110R & $2,35 \mathrm{a}$ & $11,48 \mathrm{a}$ & $24,34 \mathrm{a}$ \\
\hline Red Globe/5BB & $1,48 \mathrm{~b}$ & $4,34 \mathrm{~b}$ & $15,88 \mathrm{~b}$ \\
\hline LSD* & 0,6574 & 4,958 & 6,8102 \\
\hline
\end{tabular}

$* \mathrm{P}<0,05$ düzeyinde önemli.

Açık köklü aş11 fidanlardaki en yüksek yan kök sayısı Red Globe/1103P (10,52 adet), en düşük yan kök sayısı Red Globe/41B (3,51 adet) çeşit/anaç kombinasyonlarında saptanmış, diğer çeşit/anaç kombinasyonları arada farklı bir grubu meydana getirmiştir. En yüksek dip kök sayısı Red Globe/110R (14,69 adet), en düşük dip kök sayıları sırasıyla Red Globe/41B (10,41 adet) ve Red Globe/5BB (11,81 adet) çeşit/anaç kombinasyonlarından elde edilmiş, diğer çeşit/anaç kombinasyonları ara grupları oluşturmuştur. En yüksek toplam kök sayısı sırasıyla Red Globe/1103P (22,57 adet), Red Globe/1613C (21,31 adet), Red Globe/110R (20,84 adet) ve Red Globe/5BB (19,22 adet) çeşit/anaç kombinasyonlarında, en düşük toplam kök sayısı ise Red Globe/41B (13,92 adet) çeşit/anaç kombinasyonunda saptanmıştır. En yüksek dip kök uzunluğu ortalaması sırasıyla Red Globe/41B (24,27 cm), Red Globe/110R $(22,41 \mathrm{~cm})$ ve Red Globe/1613C $(20,86 \mathrm{~cm})$, en düşük dip kök uzunluğu ortalaması sirasiyla Red Globe/1103P $(10,93 \mathrm{~cm})$ ve Red Globe/5BB $(13,74 \mathrm{~cm})$ çeşit/anaç kombinasyonlarından alınmıştır. En yüksek dip kök skalasını sırasıyla Red Globe/110R $(3,55)$ ve Red Globe/1613C $(3,54)$ çeşit/anaç kombinasyonları, en düşük dip kök skalasını ise sırasıyla Red Globe/5BB $(2,86)$, Red Globe/1103P $(3,05)$ ve Red Globe/41B $(3,13)$ çeşit/anaç kombinasyonları 
meydana getirmiştir (Çizelge 5.).

Çizelge 5. Açık köklü aşılı fidanlarda köklenme oranına ait bazı özellikler

\begin{tabular}{|c|c|c|c|c|c|c|c|c|c|}
\hline $\begin{array}{l}\text { Çeşit/anaç } \\
\text { kombinasyonu }\end{array}$ & $\begin{array}{l}\text { Yan } \\
\text { say1s1 } \\
\text { (adet) }\end{array}$ & kök & $\begin{array}{l}\text { Dip } \\
\text { say1s1 } \\
\text { (adet) }\end{array}$ & kök & $\begin{array}{l}\text { Toplam } \\
\text { say1s1 } \\
\text { (adet) }\end{array}$ & kök & $\begin{array}{l}\text { Dip kök } \\
\text { uzunluğu } \\
\text { ortalaması } \\
(\mathrm{cm})\end{array}$ & $\begin{array}{l}\text { Dip } \\
\text { skalas1 } \\
(0-4)\end{array}$ & kök \\
\hline Red Globe/41B & $3,51 \mathrm{c}$ & & $10,41 \mathrm{c}$ & & $13,92 \mathrm{~b}$ & & $24,27 \mathrm{a}$ & $3,13 \mathrm{~b}$ & \\
\hline Red Globe/1103P & $10,52 \mathrm{a}$ & & $12,05 \mathrm{bc}$ & & $22,57 \mathrm{a}$ & & $10,93 \mathrm{~b}$ & $3,05 \mathrm{~b}$ & \\
\hline Red Globe/1613C & $7,48 \mathrm{~b}$ & & $13,83 \mathrm{ab}$ & & $21,31 \mathrm{a}$ & & $20,86 \mathrm{a}$ & $3,54 \mathrm{a}$ & \\
\hline Red Globe/110R & $6,15 \mathrm{~b}$ & & $14,69 \mathrm{a}$ & & $20,84 \mathrm{a}$ & & $22,41 \mathrm{a}$ & $3,55 \mathrm{a}$ & \\
\hline Red Globe/5BB & $7,41 \mathrm{~b}$ & & $11,81 \mathrm{c}$ & & $19,22 \mathrm{a}$ & & $13,74 \mathrm{~b}$ & $2,86 \mathrm{~b}$ & \\
\hline LSD* & 1,9794 & & 1,9246 & & 3,5964 & & 5,1163 & 0,2842 & \\
\hline
\end{tabular}

$* \mathrm{P}<0,05$ düzeyinde önemli.

Gaziantep ilinde yürütülen bir araştırmada Red Globe/110R çeşit/anaç kombinasyonunda; I. boy fidan randımanı: \%44,0, toplam fidan randımanı: \%60,0, kök sayısı: 9,0 adet ve kök gelişim düzeyi: 3,0, olarak belirlenmiştir (Aslan ve ark., 2015). Bu araştırmada ise Red Globe/110R çeşit/anaç kombinasyonunda; I. boy aşılı asma fidanı randımanı: \%53,33, fidanlık randımanı: \%76,00, toplam kök sayısı: 20,84 adet ve dip kök skalası: 3,55 olarak tespit edilmiştir.

Red Globe üzüm çeşidi özellikle 1103P ve 5BB anaçlarının üzerine aşılandığında, fidanlık şartlarında ilerleyen dönemlerde (haziran ayı) çökmeler yaparak randıman düşüklükleri meydana getirebilmektedir. Red Globe/41B ve Red Globe/140Ru aşı kombinasyonlarında ise herhangi bir sorun yaşanmadığ1 bildirilmektedir (Dardeniz, 2011). Bu araştırmada ise; Red Globe/1103P çeşit/anaç kombinasyonunda \%62,00 ve Red Globe/5BB çeşit/anaç kombinasyonunda \%63,33 düzeyinde fidanlık randımanları elde edilebilmiş olup, bu yönde olumsuz herhangi bir bulguya rastlanılmamıştır.

\section{Sonuç ve Öneriler}

$\mathrm{Bu}$ araştırmada en yüksek fidanlık randımanı Red Globe/110R çeşit/anaç, en düşük fidanlık randımanı Red Globe/41B çeşit/anaç kombinasyonunda, en yüksek 1. boy aşılı asma fidanı randımanı Red Globe/110R çeşit/anaç, en düşük 1. boy aşılı asma fidanı randımanları ise sırasıyla Red Globe/41B, Red Globe/5BB ve Red Globe/1103P çeşit/anaç kombinasyonlarında saptanmıştır.

Açık köklü aşılı fidan üretiminde elde edilen başarı birçok faktöre bağlıdır. Başarıyı etkileyen en önemli faktörlerden biri de çeşit/anaç kombinasyonunun seçimidir. Kallus gelişim düzeyi ile aş1 odası ve fidanlık randımanlarının yıllar itibarıyla farklılıklar gösterebildiği göz önüne alındığında; fidancılık açısından en uygun çeşit/anaç kombinasyonları konusunda daha doğru bir değerlendirmenin yapılabilmesi için, kombinasyonlar üzerinde daha uzun süreli (3-5 yıllık) araştırma sonuçlarına gereksinim olduğu sonucuna varılmıştır.

Not: Bu makale, Sümeyya Akçaman'ın Yüksek Lisans Tezinin bir bölümünden derlenerek hazırlanmıştır.

\section{Kaynaklar}

Alço, T., Dardeniz, A., Sağlam, M., Özer, C., Açıkbaş, B., 2015. Aşılı asma fidanı üretiminde farklı çeşit/anaç kombinasyonlarının aşı odası randımanı ile kallus gelişim düzeyi üzerine etkileri. 8. Bağcılık Semp. Selçuk Tar. ve Gıda Bil. Derg. A(27): 8-16.

Anonim, 2020. www.tarimorman.gov.tr/Bügem (Erişim tarihi: 05.06.2020).

Aslan, K.A., Özcan, S., Kösetürkmen, S., Yağcı, A., Sakar, E., Bekişli, M.İ., Kılıç, D., 2015. Gaziantep ilinde asma fidanı üretiminde farklı çeşit-anaç kombinasyonlarının karşılaştırılması. Selçuk Üniversitesi Selçuk Tarım ve Gıda Bilimleri Dergisi-A 27 (Türkiye 8. Bağcılık ve Teknolojileri Sempozyumu Özel Sayıs1). 210-216.

Balo, E., Balo, S., 1969. Wirkung der dehydratation und rehydratation auf die bewurzelung der rebstecklinge mitt. Klosterneuburg. 19: 96-101.

Beuve, M., Candresse, T., Tannières, M., Lemaire, O., 2015. First report of grapevine Redglobe virus (GRGV) in grapevine in France. The American Phytopathological Society. 99(3): 422.

Cangi, R., 1998. Anaçların asma fidanı gelişimine etkileri üzerine bir araştırma. 4. Bağcılık Semp. 20-23 Ekim, Yalova.

Çelik, H., Ağaoğlu, S., Fidan, Y., Marasalı, B., Söylemezoğlu, G., 1998. Genel Bağcılık. Sunfidan A.Ş. Mesleki 
Kitaplar Serisi: 1. Fersa Matbaacılık, Kızılay/Ankara. 253 s.

Dardeniz, A., 2001. Asma fidancılığında bazı üzüm çeşidi ve anaçlarda farklı ürün ve sürgün yükünün üzüm ve çubuk verimi ile kalitesine etkileri üzerine araştırmalar. Doktora Tezi, Ege Üniversitesi Fen Bilimleri Enstitüsü. İzmir. $167 \mathrm{~s}$.

Dardeniz, A., 2011. Aşılı köklü asma fidanı üretimi ve son gelişmeler. Bağcılık Ders Notları. $72 \mathrm{~s}$.

Dardeniz, A., Ateş, F., Çoban, H., Kahraman, K.A., Savaş, Y., Ali, B., Gökdemir, A., 2015. Günümüz asma fidancılık işletmelerinde yürütülen asma fidanı üretim faaliyetlerinin irdelenmesi. ÇOMÜ Ziraat Fakültesi Dergisi. 3 (2): 127-143.

Dardeniz, A., Gökbayrak, Z., Müftüoğlu, N.M., Türkmen, C., Beşer, K., 2008. Cane quality determination of 5BB and 140Ru. grape rootstocks Europ. J. Hort. Sci. 254-258.

Dardeniz, A., Kısmalı, İ., Şahin, A.O., 2005. Bazı sofralık üzüm çeşitlerinin aşılı fidan randımanları ile fidanlıktaki vejetatif gelişmelerinin belirlenmesi. Türkiye 6. Bağcılık Sempozyumu Bildiriler Cilt: 2. 498-505. 19-23 Eylül, Tekirdağ.

Dardeniz, A., Müftüoğlu, N.M., Gökbayrak, Z., Fırat, M., 2007. Assessment of morphological changes and determination of best cane collection time for 140Ru and 5BB. Scientia Horticulturae. 113: 87-91.

Dardeniz, A., Şeker, M., Gündoğdu, M.A., Sarıyer, T., Akçal, A., Tunçel, R., 2013. Effects of different planting heights from grafting point for grafted vine ratios and nursery yields of some grape varieties on 41B rootstock. 48th Croatian \& 8th International Symposium on Agriculture. Dubrovnik-Croatia. 294 p.

Eroğlu, D., 2014. Bazı üzüm çeşitlerinin aşılı tüplü fidan üretiminde farklı biyolojik preparat uygulamalarının etkileri. Yüksek Lisans Tezi. Adnan Menderes Üniversitesi. $81 \mathrm{~s}$.

Fan, X.D., Dong, Y.F., Zhang, Z.P., Ren, F., Hu, G.J., Li, Z.N., Zhou, J., 2016. First report of Grapevine Red Globe Virus (GRGV) in grapevines in China. The American Phytopathological Society. 100 (11): 2340.

İlter, E., Kısmalı, İ., Atilla, A., Uzun, İ., 1984. Asma fidanı sorunu ve çözümü için öneriler. Türkiye II. Bağcılık ve Şar. Semp. T.C. Tarım ve Köyişleri Bak. Bağcılık Araştırma Enstitüsü Müdürlüğü. Manisa. 23-31 s.

Kısmal1, 1979. Aşı11-köklü asma fidanı üretimi. Bitki. 6 (2): 170-180.

Kısmalı, İ., 1978. Yuvarlak Çekirdeksiz üzüm çeşidi ve farklı Amerikan asma anaçları ile yapılan aş1lı köklü asma fidanı üretimi üzerinde araştırmalar. Ege Üniv. Ziraat Fak. Meyve ve Bağ Yetiştirme ve Islahı Kürsüsü. Doçentlik Tezi. Bornova/İzmir.

Kısmalı, İ., 1981. Aşılı asma fidanı randımanına etki eden bazı etmenler üzerinde araştırmalar. Ege Üniv. Zir. Fakültesi. Bornova/İzmir. $45 \mathrm{~s}$.

Sabanadzovic, S., Abou-Ghanem, N., Castellano, M.A., Digiaro, M., Martelli, G.P., 2000. Grapevine Fleck virus-like viruses in Vitis. Archives Virology. 145: 553-565.

Tırpancı, S., Dardeniz, A., 2014. Sofralık üzüm çeşidi kalemlerinin farklı süre ve sıcaklıklarda depolanmasının üretim materyali üzerindeki etkileri. ÇOMÜ Zir. Fak. Derg. 1: 55-65.

Tuncel, R., Dardeniz, A., 2013. Aşılı asma çeliklerinin fidanlıktaki vejetatif gelişimi ve randımanları üzerine katlamanın etkileri. Tarım Bilimleri Araştırma Dergisi. 6(1): 118-122.

Uyemoto, J.K., Rowhani, A., Luvisi, D., 2000. An association of rootstock stem lesions in Vitis species and different graft-transmissible agents. In: Proceedings of the 13th ICVG Meetings. Adelaide, Australia. pp 83-4.

Walter, B., Martelli, G.P., 1997. Clonal and sanitary selection of the grapevine. In: Walter B (ed) Sanitary selection of the grapevine. Protocols for detection of viruses and virus-like diseases. Les Colloques 86 : 43-95. 